\title{
Leadership Crisis: in Decision-Making Process with Reference to Declaration of Republic in Nepal: An Anthropological Perspective
}

\author{
Khimlal Devkota ${ }^{1,2}$ \\ ${ }^{1}$ Senior Advocate, Supreme Court of Nepal, Kathmandu, Nepal \\ ${ }^{2}$ Faculty, Institute of Crisis Management Studies, Tribhuvan University, Kathmandu, Nepal \\ Email: khimlaldevkota@tuicms.edu.np,khimlaldevkota@gmail.com
}

How to cite this paper: Devkota, K. (2020) Leadership Crisis: in Decision-Making Process with Reference to Declaration of Republic in Nepal: An Anthropological Perspective. Open Access Library Journal, 7: e6395.

https://doi.org/10.4236/oalib.1106395

Received: May 3, 2020

Accepted: May 17, 2020

Published: May 20, 2020

Copyright (๑ 2020 by author(s) and Open Access Library Inc.

This work is licensed under the Creative Commons Attribution International License (CC BY 4.0).

http://creativecommons.org/licenses/by/4.0/

(c) (i) Open Access

\begin{abstract}
The main purpose of this study is to examine the historical development of leadership and crisis in leadership in Nepal. The central research question is about leadership and its role in the decision-making process, that is, is a certain leadership really matching with the right time, right content and right decision? The method used for the study was a literature review through historical and archival content analysis in the process of review of literature. The declaration of Nepal as a republic is a historical political achievement. Sources shows that, the achievement could have been made even earlier in the 1950s, and onwards political movements. But republic was only declared on May $28^{\text {th }}, 2008$. Concepts of leadership, the decision-making process and leadership crisis relate with the declaration of republic which is the main concern of the study. Complexity Leadership Theory has been used in this study in an anthropological perspective. Leadership is a key for nation, which is always confronted with questions and challenges. It is because crisis has to be handled by the leadership and leadership itself indulges in crisis. Sometimes, crisis creates leadership and sometimes leadership handles the crisis but leadership indulges in crisis most of the time. Decisions have to be taken at an appropriate time. The matching of the right time with the right decision is usually appreciated. But a wrong decision at the right time is useless. A wrong decision at the wrong time is even more disastrous. The expectations of the people and societies are always for right decisions at right times regardless of situations and limitations of the leaders. Democratic leadership, democratic processes and pro-people decisions for strengthening democracy are core concerns of the study.
\end{abstract}

\section{Subject Areas}

Political Anthropology 


\section{Keywords}

Leadership, Crisis, Decision-Making, Politics, Political Parties, Democracy

\section{Introduction}

The problem being examined by this study is that in leadership, which has been facing a crisis during the time of the decision-making process. Either decision is made with inappropriate timing or in inappropriate contexts. Why are decisions made by leadership not matching with the right timing? What are the causes and consequences? What factors are playing a role? These are the questions which expect appropriate investigation and answers. This paper tries to investigate the core concept of leadership, the working style, qualities, and state of mind of the leadership during the time of making decisions. This study is important because institutions, societies and nations are facing numerous problems because of leadership. Leadership either they are failing to lead the institutions, society, political parties and nations or they are indulging in confusion in particular times of decision making. The impact of indecisiveness and lack of leading capacities societies will suffer, people will suffer and societies will lag behind. The study is not claiming as a final and complete research rather it will open up the avenue of the further research for the betterment of the nation societies and political parties. Based on this study further research will be more practical and effective. The paper is largely based on review.

Leadership is generally a domain of inquiry under the political science. However, many pioneer anthropologists have made significant contributions to understand leadership from socio-cultural perspectives. According to Clifford "Leadership is political representations and their leadership through their culture" (Clifford \& School of American Research, 2008, p. 2) [1]. The cultural factor is playing a vital role to shape up the leadership has given by anthropologist, I partly agree with these ideas. In addition to culture, the given power structure, social and economic condition is also equally important, according to Geertz ((1973) "an interpretation of the theory of culture, as a perception of Leadership" (Geertz, 1973) [2]; according to Mead (1928) focus on "powers of leadership" (Mead, 1928, p. 64) [3]; according to Malinowski (1921) "Basic concept of leadership and its different field and situations" (Malinowski, 1921, p.18) [4]. I do agree with Malinowski, that there are varieties of factors for shaping leadership. In the every societies people are the most which is more focused by anthropologists stating that "within the people" focuses by Evans (Evans-Pritchard \& Gillies, 1976, p. 14) [5] and gender has focused by Strathern with explanation of social, cultural, and ecological connections (Strathern, 2001) [6]. It is relevant in my research because leadership in the society and its impacts through social, cultural and ecological aspects in general and in the specific context of Nepal, along with others, the impact of a feudal mode of production, is more important. 
Country; lead by Monarchy since almost 250 years not because of their leadership quality. There is no doubt people are decisive however people also influenced by the given socio-economic and cultural conditions. According to Sahlins, (1972) "we should first consider the structural and ideological means by which power in the primitive societies is realized in production" (Sahlins, 1972, p. 131) [7].

Nepali anthropologists mostly focus on education. According to Dilli Ram Dahal, “... serious ethnographic research ....” (Dahal, 2016) [8]. According to Mukta S. Tamang, Suresh Dhakal and Janak Rai on Nepal's school of anthropology, "as envisioned by the founding members is now to be realized for which required ground work appears to have been in place" (Mukta S Lama, 2016) [9] is very encouraging to me for my topic. Based on the above-mentioned facts, there has been proof that leadership and their decision-making process are affected by the culture and surrounding environment. In the case of Nepal, the cultural part is indecisive. The societal condition is feudal and the behavior is a byproduct of the given condition. According to Marx quoted by Katz "capitalist production provides an analysis of the process that broke up feudal class relations, giving rise to a capitalist class enjoying private ownership of the means of production facing a working class owning nothing but their labor power." (Katz, 1993) [10]. As explained by Marx, the condition of Nepal has therefore faced numerous problems of that kind. However, the neighboring countries completed their revolution around the 1950's. Nepal failed to abolish monarchy. Nepali leadership fought for democracy continuously since before the 1950's until 2008. But they compromised; time and again. But, why they did so? This is a big question.

The research is divided in to seven main sections. In addition to abstract the first section introduction tries to conceptualize the political leadership and their crisis generally around the world and specifically focus on Nepal. Second section is talking about research method mainly literature review with archival content analysis with anthropological perspective. Third section is theoretical foundation mainly based on complexity leadership theory. Fourth section is dealing with result and findings on leadership, decisions and crisis. Fifth section is full of discussion and final section is conclusion with limitation and findings of the research.

\section{Method}

The study approach of the paper is largely based on archival sources. Data and information collected on leadership, the decision-making process, and indecisiveness while making crucial decisions mainly during crisis-handling are from published sources and analyzed. On the other hand, while handling leadership during crisis, they indulge in confusion. Based on the scattered literature, the paper has organized. Leadership is a key to the success and failure of the institution, nation, politics and any other missions. Therefore, the study tries to explore 
a better understanding of leadership and finding some qualities of leadership through review of literature. How they failed and succeeded in their mission is the main area of inquiry for this paper. In this study, historical archival content analysis has been used.

Archival research methods include a broad range of activities applied to facilitate the investigation of documents and textual materials produced by and about organizations. In this study it has been used mostly for decisions, news and views of political parties related to the declaration of a republic along with the study of archival historical documents to relate political, social and cultural context of its time. Party decision has been taken from respective party offices and news and views has been taken from archival library especially from the press council of Nepal, the central library, Kirtipur, Central Law Library and others. The main concern of the discourses for decision of declaration of a republic from 2006 to 2008 is in focus. In the study, the collected data has been analyzed based on their cultural, social and political conditions. Which particular conditions decisions have been made in? What level of relevance could be in Nepali context has been well taken.

For the purpose of data analysis, first of all data was collected from historical archival studies, national to international, level with the help of well-known scholars. Collected data has been classified on leadership, its qualities, working style, and decision-making process comparing with different models, synthesized and analyzed in line with different theories of leadership. More specifically, the collected data has been analyzed in the decision-making process at their level of decisiveness or indecisiveness in the context of declaration of republic in Nepal, and broadly on leadership crisis in Nepal and beyond.

\section{Theoretical Foundation}

Complexity Leadership Theory has been used in this study. According to Brown \& Briown "it reflects the complexity of the real world, increases the relevance of our leadership theories, and provides new insights for students, researchers, and managers in the complex world of business" (Brown \& Briown, 2011, p. 9) [11], (Alase, 2017) [12] While the entire theory is more complex than this, this definition is useful as it encompasses three fundamental characteristics of complex systems: they involve interacting units, are dynamic, and are adaptive. Complexity leadership could be defined as adaptive mechanisms developed by complex organizations in new conditions required by the information age, rather than technical problems entailed by the industrial age.

The study is relevant with complexity leadership theory; it is because it deals with interacting with individuals, concerned stakeholders and leadership for problem-solving methods. It is to identify the root cause of problems and appropriate solutions in the field and leadership. It is a theory mainly shifting from Industrial to Knowledge era. The Nepali society has rapidly shifted from Feudalism to Industrialism then Knowledge and Information age. Politically led Nepali 
society was able to abolish about 250 years' monarchy and adapt to being a federal republic country in the $2^{\text {nd }}$ decade of the $21^{\text {st }}$ century, it is appropriate to follow the complexity theory. Having this specific condition of the society, complexity leadership theory is better than others.

\section{Results/Findings}

\subsection{Leadership Development in the Context of Nepal}

Compared with the leadership theories and leadership studies around the world there are not sufficient studies on leadership suit for Nepali context. This paper is based on the political history after the unification of the country. Inferences can be drawn from different theories and practices into our Nepali context. Nepal has facing leadership challenges from the Rana regime to Shah Regime. In terms of democracy, development, and good governance people are considered failed leadership. In terms of political stability and participation in the decision-making process, leadership everywhere failed to face crisis at their own time. Even after the emergence of the modern age, leadership has always been in question. The wave of democracy prevailed everywhere, however Nepal was in a closed and party-less society. Continuation of the past feudal political system even in the modern age was because of leadership's poor quality, indecisiveness, and crisis. The cause of leadership crisis and failed leadership was not because of leadership itself; rather it was because of the socio-economic condition of the Nepali society, which is substantiated by Bumsoo Kim and Sunhyuk (2013) as the authors stated "in the field of democracy studies, a similar debate focuses on the question of whether citizens in a democracy prefer different leadership depending on culture" (Kim \& Kim, 2013, p. 388) [13]. The concept of Nepali leadership emerged from a feudal mode of production. Feudal mode of production never allowed an equal and democratic culture. Leaders and followers relationship was considered a patron-client relation and not in equal footing. Feudal mode of production and feudal culture prevailed everywhere in Nepali politics and leadership. However, shifting from a feudal mode to a capitalism and knowledge era, it is relevant to use Complexity Leadership Theory which can be used to deal with individual to institution. Therefore, my study is relevant with this theory. Looking at the history of leadership, it has been made by two processes i.e. by birth and by revolution/movement. The leadership of the Rana regime was mainly by birth. However, at the time of Shah Regime, except for the monarchy, leadership was made by revolution. The picture of the political system of Nepal can be explained as mentioned in Table 1.

In interaction with the senior leaders of ruling and opposition parties, they are proud of their decisions mostly but some of the decisions they regret. Chairman of the Nepal Communist Party (NCP), Pushpa Kamal Dahal voiced "the decision of initiating people's war and a peace process were right decisions at the right time, because of people's war and peace process we achieved the major political achievement of federalism, republicanism, secularism and inclusion". Resignation 
Table 1. Political system.

\begin{tabular}{cccc}
\hline S.N. & System of Politics & Characteristics of Politics & Kinds of Decisions \\
\hline 1 & Partyless Panchayat & Feudal & Decisive, wrong decision in wrong time \\
2 & Multiparty & Semi-feudal & $\begin{array}{c}\text { Indecisive, right decision in wrong time } \\
\text { or wrong decision in right time }\end{array}$ \\
3 & Republican & Moving towards capitalism & $\begin{array}{c}\text { Right decision in right time the } \\
\text { declaration of republic }\end{array}$ \\
\hline
\end{tabular}

of the Prime Minister was the right decision at the wrong time. Government handover to the sitting Chief Justice was the wrong decision at the wrong time. However, its consequences were satisfactory. Chairman of the main opposition party, Nepali Congress (NC) Sher Bahadur Deuba narrated, the decision of declaration of republic taken by the party was too late, and because of that it backfired in the election. Most of the leaders from ruling and opposition parties are in the same line of leaders. Generally, decisions were taken by the top leaders and have been disseminated to all-owned and disowned by the peoples and followers based on their own likes and dislikes. In this scenario, leadership has been tested based on their decisions. Pro-royalist party leader Kamal Thapa told me in private conversation, "the decision of removal of monarchy is a grave mistake and history will prove it". He stressed again, "Nothing has been mentioned in the 12-point understanding about removal of monarchy." Journalist Youbraj Ghimire voiced, "Removal of the monarchy was not mentioned in the 12-point agreement." There was only the use of the word "full democracy". The agreement between monarchy and seven party alliances was to accept titular king which was proven by the popular declaration of May 18, 2006 done by the re-instated parliament. According to the then Maoist leader Dr. Baburam Bhattarai, "the word used in the 12-point understanding of 'full democracy' was with the tacit understanding that it referred to a republic. The Maoist party disseminated it as a republic however those parties that were yet to be decided on a republic were the great excuse of the constitutional monarchy." NCP leader Madhav Kumar Nepal, who has written note of dissent in interim constitution with the proposal of referendum instead of that the fate of monarchy will be fixed by the simple majority of the constituent assembly in the first meeting. The very fact was that, declaration of republic proposal indorsed in December 23, 2007 in the parliament the proposal was put forwarded by the Maoist party, the house was divided and voting had taken placed. Nepali Congress and other pro-royalists stood for monarchy. These events are all related to the decision-making process with reference to the declaration of a republic in Nepal.

\subsection{Decision-Making}

Leaders are almost always involved in decision-making process, whether formal or informal. Taking a decision as is also a very important to his/her life. We must remember that people are leaders primarily because they chose to be. Moreover, 
good leadership is to a large extent a choice. According to Selart (2010) "leadership means to guide future leaders in how they should make decisions. It also involves providing future leaders with guidance on how they should implement, evaluate and monitor their decisions" (Selart, 2010, p. 11) [14]. Decisions are in everyday business and they depend on the output of the different actors in every phase of life. According to Okoro (2016) "Lack of support of the key actors, and failure in attending to the interests and information from them could lead to a failure in the decision-making process" (Okoro, 2016) [15]. Johason says "We want quality of decision" (Riggle \& Johnson, 1996, p. 116) [16]. Professor Kellerman has devised three more models that focus on the role of small groups, the impact of the dominant leader, and the effects of the "cognitive process" on decision-making (Kellerman, 1983, p. 351) [17]. Anthropologists have always been interested in interrelations between institutions. According to Howard \& Ortiz (1971) "Decision-making analysis needs to be more than anecdotal, reasoning and cognitive processes" (Howard \& Ortiz, 1971, p. 213) [18]. According to Mohanty (2011) during liberalized era of India "moved from a state-led commanding economic pattern to a market-friendly economy" (Mohanty, 2011, p. 511) [19]. Whereas Johnson argues "Camp level decisions affect major aspects of nomadic life," (Johnson, 1983, p. 180) [20]. Decision made by whom and how is a big question in every field of society. Theoretically, participatory decision-making process is considered as the best practice in every field. Such a decision is possible in open and democratic societies. Decision made by the political leadership is a key of politics. Some of the decisions and their focus has mentioned in Table 2.

In Nepal's context, the decision-making process is also heavily influenced by a feudal mode of production and cultural traits. A decision made by a few and imposed to all is known as the feudal mode of decision-making. Pro-people decisions and peoples' participation in decisions never happens in the feudal regime. Now the situation has been changed from monarchy to republicanism and the mode of production has been changed from feudal to capitalistic. As Marx says about base and superstructure, Nepal has changed its superstructure; however, the base is yet to be changed. Therefore, leadership style, theory and practices also have to be changed accordingly. Thus, Complexity Leadership Theory

Table 2. Decision making process and focus.

\begin{tabular}{ccc}
\hline S.N. & Literature & Focus \\
\hline 1 & Selart & Implementation, evaluation and monitoring \\
2 & Okoro & Participatory approach in decision making process \\
3 & Kellerman & Cognitive process \\
4 & Howerd \& Qrtiz & Anecdotal, reasoning, cognitive process \\
5 & Mohanty & State to Market leadership \\
6 & Johnson & Participatory process in decision making process for implementation \\
\hline
\end{tabular}


is relevant for this study.

\subsection{Leadership Crisis}

Crisis management, it seems, is unable to abate escalating crises in increasingly risk-dominated economies. Economics, politics, and public duty have to be reconciling each other. According to Kouzmin (2008) "Crises is not a problem always, sometimes it is opportunity" (Kouzmin, 2008, p. 155) [21]. Likewise Govea \& Holm (1998) "political crisis is the critical obstacle to a regulated succession, more important than either economic or cultural crises" (Govea \& Holm, 1998, p. 129) [22]. The failure of Iran's new leadership Petrossian (1981) claim that "deficiency shared by nearly all groups" (Petrossian, 1981, p. 39) [23]. According to Fanso (1979) “during its civil war and reconciliation, required an ability of the highest kind in directing the affairs in its hour of great need" (Fanso, 1979, pp. 48-49) [24]. According to Wallace\& Suedfeld (1988) refer their analysis that "the ability to maintain conceptual complexity under the stress of crisis is closely linked with the ability to resolve the crisis without resorting to war" (M. D. Wallace \& Suedfeld, 1988, p. 439) [25]. Questioning to war and attack Cothran \& Phillips (1961) praised non-violent movement as "questions the legitimacy of the application of power by the white community to maintain the existing system of race relations" (Cothran \& Phillips, 1961, p. 118) [26]. Chinese leadership fell back on traditional methods to deal with the crisis of economic inefficiency whereas strong leadership of Chairman Mao was available. Even though they were suffering from "the cage economy," then According to Hsin-Chi (1991) started "the rekindling of the Maoist mass line and the renewal of the "Learn from Lei Feng' campaign” (Hsin-chi, 1991, p. 22) [27].

According to Ahmed (2007) Somalia has facing "Leadership crisis and conflicting identities" (Ahmed, 2007, p. 272) [28]. Haruna (2009) refer for "social change and institutional transformation" through cultural community. (Haruna, 2009, p. 941) [29]. According to Issa and Devid, “Africa's failures have come about largely as a result of frequent leadership change, lack of ideology" (Issa \& David, 2012, p. 141) [30]. According to Chang the only solution is "collective leadership" (Chang, 1974, p. 107) [31]. In the African context, Baker (1998) suggests to "traces their subsequent history" (Baker, 1998, p. 115) [32].

American are also facing the problem of leadership crisis as Lerche (1966) argues "US is one of the landmark challenges of the century" (Lerche, 1966, p. 321) [33]. According to Karenga (1982) realizing the black and white leadership "both in terms of the added pressures for solutions which it brings as well as the increased difficulties it poses to reaching socially effective solutions" (Karenga, 1982, p. 16) [34]. According to Moore (1999) there are close link with development as "agrarian struggle counter a recent tendency toward discursive determinism in anthropological perspectives on development” (Moore1999, p. 654) [35].

In the case of Nepal, the Rana regime indulged in how to lead people and the 
nation with the use of power to suppress democracy. Nepali congress leader, BP Koirala, indulged in crisis whether by compromising with the King or launching revolution. Even after the restoration of democracy, the leadership indulged in political crisis. The issue of crisis was, whether amendment of the constitution that suppresses the anti-Constitutional element naming them anti-national element. During the Maoist movement state and non-state actors both indulged in crisis. State actor indulged in crisis whether suppressing the Maoist or compromising; at the same level Maoist leadership was in crisis whether by continuing revolution or compromising at some point in time. The nation indulged in the crisis of leadership whether by accepting the demand of the election of the Constituent Assembly or establishing republicanism and federalism. Leadership around the world has been facing their crisis and indulged which can be seen as mentioned in Table 3.

Based on above discussion social scientists consider that there is a leadership crisis in Nepal. However, they have not given fixed indicators for good leadership and bad leadership development. Therefore, leadership relies on time and context. When we are talking about Nepal the crisis of leadership and decisiveness is much poorer unlike the above-mentioned facts. Rana to Monarchy rule, throughout the centuries the country lags behind. Despite Rana and Shaha and all others rulers also has been faced number of crisis and failed to face it were democracy, political stability and development. Ultimately people suffered from lack of development and good governance. According to Baral (1980), "The Panchayat System is either going to disintegrate or be modified drastically as a result of the referendum of 1980 that was ordered by King Birendra on May 24, 1979 on whether the Nepali public prefers to continue the existing system with

Table 3. Leadership crisis and Nature.

\begin{tabular}{|c|c|c|}
\hline S.N. & Country & Nature of Crisis \\
\hline 1 & $\begin{array}{c}\text { Iran- } \\
\text { Iran's Crisis of Leadership by Vahe Petrossian }\end{array}$ & $\begin{array}{c}\text { Deficiency shared by nearly all } \\
\text { groups }\end{array}$ \\
\hline 2 & $\begin{array}{l}\text { India- } \\
\text { Leadership in Political Movements: Comparative Study of } \\
\text { Sheikh Mohammad Abdullah and Sheikh Mujibur } \\
\text { Rahman by Mohamad Zakaria }\end{array}$ & Leadership and identity politics. \\
\hline 3 & $\begin{array}{l}\text { China- } \\
\text { Great Leap forward Chinese leadership in crisis by } \\
\text { Gordon G. Chang }\end{array}$ & $\begin{array}{l}\text { Generals and admirals playing } \\
\text { more prominent roles }\end{array}$ \\
\hline 4 & $\begin{array}{l}\text { Somalia- } \\
\text { Reflections on Historical and Contemporary Islam in } \\
\text { Ethiopia and Somalia: A Comparative and Contrastive } \\
\text { Overview by Hussein Ahmed }\end{array}$ & Conflicting identities \\
\hline 5 & $\begin{array}{c}\text { America- } \\
\text { The Crisis in American World Leadership by Charles O. } \\
\text { Lerche }\end{array}$ & $\begin{array}{l}\text { Black and white leadership as } \\
\text { racist politics }\end{array}$ \\
\hline 6 & $\begin{array}{l}\text { Nepal- } \\
\text { Nepal 1979: Political System in Crisis, By Lok Raj Baral }\end{array}$ & $\begin{array}{l}\text { Feudal King to Republican } \\
\text { Maoist }\end{array}$ \\
\hline
\end{tabular}


gradual reforms or to opt for a multi-party system" (Baral, 1980, p. 197) [36]. Either a natural calamity or a state-induced crisis seems to be fall Nepal every year, which gives the government a much-needed excuse for everything from low growth to environmental degradation (Koirala 1990, p. 143) [37]. According to Hathhethu "the entry of an insurgent group, the Communist Party of Nepal (Maoist) or the CPN (Maoist) championing for a republican system, as one of the dominant actors making the future of Nepal This is one strong indicator about where Nepal is heading as far as the future of monarchy is concerned" (Hachhethu, 2007, p. 1828) [38]. According to Crossette "Both sides appear willing to risk renewed violence across an ethnic and linguistic divide" (Crossette, 2005, p. 76) [39].

With this scenario, the leadership crisis of Nepali politics is closely linked with politics and their decision-making process. The social structure of Nepali society is divided by class, caste, sex, and territorial disparity. The root cause of the problem has to be resolved by forward-looking restructuring of the state with socio-economic transformation with declaration of republic which was the main objective of the peace deal. This is an exemplary work of leadership to overcoming prevailing crisis which was responsible to overcome the then leadership crisis. This diversity has to be considered as an asset of the nation but the then rulers took as a burden of the society. With such a mindset and the given social structure was favorable to creating crisis. Cultural practices always deepen crisis, participation was frustrating and confining for the few top leaders with a feudal mindset. Ultimately the consequence is political crisis. If leadership is able to show decisiveness, adopting participatory processes and agreeing to restructuring of the states, then crisis can be resolved otherwise it deepens more.

\section{Discussion}

\subsection{Leadership}

Common understanding of leadership is to lead a society, institution, organization, or political parties. Specifically from the approach of anthropology, it is quite interesting to focus on human values, power, institution and role of society. Clifford Geertz (1973) [2] writes on an anthropological perspective, while Malinowski, B. (1922) [4], writes on the basic concept. Boas (1911) [5] focuses on their civilizations, their birth, status, and so on. It means the concept of leadership has different meanings and different effects in different civilizations. However, there is no fundamental difference in the ways of thinking of primitive and civilized people. Sahlins, focuses on leadership structure (Sahlins, 1972, p. 131) [7]. From an anthropological perspective, this study is mostly being beneficial. However, because of the modern age the concept and style of leadership has been changed a lot. Other than that changing variable, my study is fully supported by anthropological literature with the appropriate application of an anthropological lens. Leadership-making is a dynamic process which is which is based on time, space, and context. 


\subsection{Decision Making}

Decision-making is a buzzword in the development world lexicon. It is also a contested concept in different political regimes. It is widely considered that leaders are for making decisions and this is focused on by Selart (2010) [14] in his research work. Likewise, Okoro (2016) [15] stated that decisions are in everyday business and they are dependent on the output of the different actors in every phase of life. Decisions vary by age factors as stated by Riggle \& Johnson (1996, p. 116) [16]. Graham Allison offered a set of three models to improve our understanding of the decision-making process in government, with special reference to foreign affairs. Professor Keller man has devised three more models that focus on the role of small groups, the impact of the dominant leader, and the effects of the "cognitive process" on decision-making (Keller man, 1983, p. 351). Anthropologists have always been interested in the outcome of these choices either because they reflect ongoing change or because they elucidate interrelations between institutions. By leadership and their decision "India moved from a state-led commanding economic pattern to a market-friendly economy" (Mohanty, 2011, p. 511) [19], which is very encouraging for this study. Leadership should be a game changer. Since 1950s, Nepali people had been waiting for a republic. Therefore, the Mohanty study is very helpful. A decision has to be taken based on concrete analysis of a situation and based on reality checks. The challenges and opportunities must be based on proper diagnosis. According to Johnson (1983) "Decisions not only in modern society but also in nomadic life are the same but the processes and focuses are different" (Johnson, 1983, p. 180) [20]. It is suggested, on both theoretical and empirical grounds that both, central tendency and maximum potential range of variation in camp size among a variety of pastoral nomadic groups, is heavily constrained by limitations on the ability of individuals and small groups to monitor and process information in decision-making contexts. However, even though it can be taken into account in the context, as it is not really useful for this study, just inferences can be drawn.

\subsection{Leadership Crisis}

The concept of leadership always follows the path of the right decision-making process. When leadership indulges in indecisiveness then decisions would have been incorrect. Ultimately, the question and crisis will emerge on leadership self forever. According to Kouzmin (2008), "even though crisis is not always a problem, however, it is an opportunity” (Kouzmin, 2008, p. 155) [21]. Africa’s long history shows crisis with Islam, and an appreciation of the role that revivalist movements play in youthful societies coping with the dislocating effects of globalization. According to Govea\&Holm (1998) political crisis is the critical obstacle to a regulated succession, more important than either economic or cultural crises (Govea \& Holm, 1998 p.129) [22]. According to Wallace "Crisis is not taken since optimists and pessimists both have been wrong about India and 1968 is to be taken as a year illustrative of the Indian political system" (P. Wallace, 
1969, p. 79) [40]. According to Petrossian (1981) Iran's new leadership to come up with early solutions, however, its image at home and abroad was far too untidy for explanations (Petrossian, 1981, p.39) [23].

According to Fanso ((1979), Africa managed to come through the numerous crises with keep on integrity. (Fanso, 1979, p. 48-49) [24]. Since the 1920's it can be considered the structure which represents the integration of the Navajo (Donald, 1970, p. 867) [41]. By arguing Wallace\&Suedfeld (1988) "crisis is closely linked with the ability to resolve the crisis without resorting to war" (Wallace \& Suedfeld, 1988, p. 439) [25].As Hasan (1998) says "social base, ideological orientation and contrasting styles of leadership in Pakistan left their imprint on the course even after independence" (Hasan 1998, p. 585) [42]. According to Ahmed (2007) Somalia facing "political anarchy, leadership crisis and conflicting identities" (Ahmed, 2007, p. 272) [28]. Haruna (2009) identify the area of social change and institutional transformation with examining leader characteristics, skills, styles, and behaviors in unique contexts (Haruna, 2009, p. 941) [29], While Baker (1998) proposes to transform from the beginning of the democratic movement (Baker, 1998, p. 115) [32]. If it is a uni-polar world, US's role is expected to adequately have a major effect on the course of history during the decades that lie ahead (Lerche, 1966, p. 321) [33]. According to Cothran \& Phillips (1961) the Negro problem is about the question of "sold out" to whites. (Cothran \& Phillips, 1961, p. 366) [26]. This societal crisis sharpens the historical crisis in black leadership and makes it a more urgent and demanding task by addressing their sentiment. However Karenga (1982) hints us "to reaching socially effective solutions” (Karenga, 1982, p. 16) [34]. Moore (1999) focuses Zimbabwean nationalism "a recent tendency toward discursive determinism in anthropological perspectives on development" (Moore, 1999, p. 654) [35]. Chinese leadership had moved towards "the cage economy, to mass line" and "collective leadership" to solve leadership crisis during the Mao era. (Hsin-chi, 1991, p. 22) [27], (Chang, 1974, p. 107) [31].

Based on above discussion, in contemporary Nepali politics and leadership, the role of the king was in the same situation therefore the reviewed literatures are very relevant for my study. In the case of Nepal, Baral (1980) [36], Hatchhethu (2007) [43], Koirala (1990) [37], Crossette (2005) [39], Dastider (2001) and others equally argue that political leadership is in crisis. They express similar views on leadership crisis in the panchayat and monarchy-led systems, which substantiate by indecisiveness of the leadership of its time. My assumption has reconfirmed by the reviewed available literature. Political change, struggle and revolution are a must at a point of time but leadership also must be there. Political background of the declaration of republic was full of crisis has been qualified by reviewed literatures. The reviewed archival historical literatures and decisions, news and views of the political parties and leaders show that leadership was indecisive. Thus, the country suffered from the monarchy for more than enough of a period of time. Parties and people suffered for more than enough 
time having absolute majority in favor of republic.

\subsection{Declaration of Republic}

If leadership was on the right track, republicanism would had been declared in the 1950's when the then king Tribhuvan had self-declared Nepal would be a republic with the constitution made by peoples' elected representatives. The given fact proved that, leadership failed to grasp the opportunity at that particular point of time. Politics moved ahead towards parliamentary election under active monarchy instead of election of Constituent Assembly. The elected government was dismissed by the then king and imposed party less Panchayat system in 1961. Even at that time leadership failed to protest as expected. In 1972, a leftwing party initiated an armed struggle against the monarchy again badly controlled by the regime. In 1981 the regime announced a referendum but parties were divided and the result served the same. The peoples' movement of 1990 's again with popular support meant that the monarchy was about to give up its power but leadership again compromised with the king and accepted the parliamentary democracy constitutional monarchy. In 1996, the Maoist initiated again an armed struggle against the monarchy. The regime countered with an urgent counterattack with the help of the slogan "war against terrorism". After a decade-long armed struggle settled through negotiation again the issue of monarchy was postponed in the $1^{\text {st }}$ meeting of the constituent assembly. Big questions were there, if the election of the constituent assembly never happened then the status of the monarchy would be the same. Finally, and luckily, an election took place and a provision of an interim constitution was implemented with rigorous effort then only after the country had been declared federal democratic republic.

Based on the reviewed literature, several crises have been managed by the leadership of the respective countries. Nepal is also one peculiar example of handling, facing and indulging and overcoming the crisis. My assumption has been fulfilled with the help of the above-mentioned literature and their findings. The concept of leadership, decision making process is a key topic for my study. Leadership indulges in crisis which has been proved by research. But there is a gap in study of leadership crisis in the process of taking decision of declaration of republic in transition country like Nepal has not found. Because of leadership crisis the declaration of republic has been done too late only in May 20, 2008. The counter arguments can be made that if the monarchy had been abolished before that, the country itself would have been at stake.

\section{Conclusion}

With the overall objective of the paper to examine an understanding of the concept of leadership, the decision-making process and leadership crisis are in the specific context of the declaration of republicanism in Nepal, based on the available literature. By taking those points may seem somewhat theorizing the 
leadership indulge in indecisiveness examined which is the glimpse of the research.

\section{Limitation of the Study}

Leadership crisis, decision making process and declaration of republic in Nepal are a main concern of the research. Firstly, based on literature, content analysis and anthropological perspective, therefore research may have limitations. Secondly, Nepali few party leaders consulted and their views analyzed based on available literatures of leadership crisis from very few countries and authors therefore very limited areas has been covered. Thirdly, Qualitative approach has been used. Based on others experiences and references have been in the decision making process in the Nepali context only the case of declaration of republic. Fourthly, for the purpose to reveal historical perspective old literature has been used. Therefore the research is very limited approach though leadership qualities, decision making process decisiveness and indecisiveness are the huge areas of research has been identified for further research. Due to time and resource constraint research has been done in limited theme even though it is really useful for future.

\section{Findings}

The research began with the concept of the leadership with anthropological perspective focusing on decision making process with the context of declaration of republic in Nepal, following conclusions can be drawn.

1) The concept of leadership is not only to lead the society but also to integrate and connect the people and society. Leadership is focused on humankind. Culture, power and societal structure are core component to play vital role to shape up leadership.

2) Decisiveness is a quality of leadership. Whether leadership assert their decisiveness crisis will resolve. In this context Nepali leadership has done historical task though, sometimes leadership itself creates the crisis is also obvious, most of the time leadership indulges in crisis. Leadership is a key player in politics which has been revealed in interaction with them.

3) Decision-making processes and their decisiveness are based on leadership practices. Leadership practice itself is responsible to create and to resolve crisis. Having complex societies with dynamic leadership has been demanded to resolve multiple problems through Complexity Leadership Theory.

4) Indecisiveness of the leadership on republicanism was the direct function of the feudal political culture and behavior of leaders which was largely triggered by feudal mode of production. Declaration of republic in 28 may 2008, which is not bad but it had to be achieved earlier than that or in the 1950's. Even in 2008 leadership crisis came up finally decisiveness prevailed.

In summary, the present study has shown that leadership is a key factor to lead society no matter developed or developing, stable or in transition all are 
equally facing crisis as per their given condition and structure of the society. But qualitative leadership handles the crisis amicably and sometimes leadership creates and deepens the crisis more with their capacity.

\section{Conflicts of Interest}

The author declares no conflicts of interest regarding the publication of this paper.

\section{References}

[1] Clifford, J. and School of American Research (2008) Writing Culture: The Poetics and Politics of Ethnography; a School of American Research Advanced Seminar (Nachdr.). University of California Press, Berkeley, CA.

[2] Geertz, C. (1973) Interpretation of Cultures. New York.

[3] Mead, M. (1928) Coming of Age in Samao. William Morrow and Company, New York.

[4] Malinowski, B. (1921) Argonauts of the Western Pacific, an Account of Native Enterprise and Adventure in the Archepealouges of Melanesia of New Gueana. Wolne Lektury prezez fundac, Nowoczesna Polska.

[5] Evans-Pritchard, E.E. and Gillies, E. (1976) Witchcraft, Oracles, and Magic among the Azande (Abridged with an Introduction by Eva Gillies). Clarendon Press, Oxford.

[6] Strathern, M. (2001) The Gender of the Gift: Problems with Women and Problems with Society in Melanesia (Nachdr.). University of California Press, Berkeley, CA.

[7] Sahlins, M.D. (1972) Stone Age Economics. Aldine-Atherton, Chicago, IL.

[8] Dahal, D.R. (2016) Anthropological Tradition in Nepal: History and Practices. Nepali Anthropology: New Direction and Contribution. Central Department of Anthropology, Tribhuvan University, Kritipur, Kathmandu, 36.

[9] Mukta, S. and Lama, S.D. (2016) Nepal School of Anthropology: Emerging Issues and Future Directions. Nepali Anthropology New Direction and Contributions. Central Department of Anthropology, Tribhuvan University, Kritipur, Kathmandu, 125.

[10] Katz, C.J. (1993) Karl Marx on the Transition from Feudalism to Capitalism. Theory and Society, 22, 363-389. https://doi.org/10.1007/BF00993533

[11] Brown, B.C. and Briown, B.C. (2011) Complexity Leadership: An Overview and Key Limitations. 14

[12] Alase, A. (2017) Emerging Leadership Conceptualization: The Complexity Leadership Theory. Australian Academy of Business and Economics Review, 3, 200-206.

[13] Kim, B. and Kim, S. (2013) Does Culture Determine Democratic Leadership in East Asia? The Case of South Korea during the Roh Moo-hyun Presidency. Asian Perspective, 37, 387-408. https://doi.org/10.1353/apr.2013.0015

[14] Selart, M. (2010) A Leadership Perspective on Decision Making.

[15] Okoro, F. (2016) Actors and Roles in Decision Making Process.

[16] Riggle, E.D.B. and Johnson, M.M.S. (1996) Age Difference in Political Decision Making: Strategies for Evaluating Political Candidates. Political Behavior, 18, 99-118. https://doi.org/10.1007/BF01498661

[17] Kellerman, B. (1983) Allison Redux: Three More Decision-Making Models. Polity, 
15, 351-367. https://doi.org/10.2307/3234666

[18] Howard, A. and Ortiz, S. (1971) Decision Making and the Study of Social Process. Acta Sociologica, 14, 213-226. https://doi.org/10.1177/000169937101400401

[19] Mohanty, C. (2011) Decision-Making Process on Policy of Liberalization in Indian State. The Indian Journal of Political Science, 72, 511-512.

[20] Johnson, G.A. (1983) Decision-Making Organization and Pastoral Nomad Camp Size. Human Ecology, 11, 175-199. https://doi.org/10.1007/BF00891742

[21] Kouzmin, A. (2008) Crisis Management in Crisis? Administrative Theory and Praxis, 30, 155-183. https://doi.org/10.1080/10841806.2008.11029631

[22] Govea, R.M. and Holm, J.D. (1998) Crisis, Violence and Political Succession in Africa. Third World Quarterly, 19, 129-148.

https://doi.org/10.1080/01436599814569

[23] Petrossian, V. (1981) Iran's Crisis of Leadership. The World Today, Royal Institute of International Affairs.

[24] Fanso, V.G. (1979) Leadership and National Crisis in Africa: Gowon and the Nigerian Civil War. Présence Africaine, 109, 29. https://doi.org/10.3917/presa.109.0029

[25] Wallace, M.D. and Suedfeld, P. (1988) Leadership Performance in Criszzis: The Longevity-Complexity Link. International Studies Quarterly, 32, 439-451. https://doi.org/10.2307/2600592

[26] Cothran, T.C. and Phillips, W. (1961) Negro Leadership in a Crisis Situation. Phylon, 22, 107-118. https://doi.org/10.2307/273448

[27] Hsin-chi, K. (1991) Political Leadership and Development. 26.

[28] Ahmed, H. (2007) Reflections on Historical and Contemporary Islam in Ethiopia and Somalia: A Comparative and Contrastive Overview. Journal of Ethiopian Studies, 40, 261-276.

[29] Haruna, P.F. (2009) Revising the Leadership Paradigm in Sub-Saharan Africa: A Study of Community-Based Leadership. Public Administration Review, 69, 941-950. https://doi.org/10.1111/j.1540-6210.2009.02043.x

[30] Issa, S. and David, K. (2012) The Challenges of Leadership and Governance in Africa. International Journal of Academic Research in Business and Social Sciences, 2,17 .

[31] Chang, P.H. (1974) The Chinese Leadership Crisis. Asian Affairs, 2, 100-107. https://doi.org/10.1080/00927678.1974.10587655

[32] Baker, B. (1998) The Class of 1990: How Have the Autocratic Leaders of Sub-Saharan Africa Fared under Democratization? Third World Quarterly, 19, 115-127. https://doi.org/10.1080/01436599814550

[33] Lerche, C.O. (1966) The Crisis in American World Leadership. The Journal of Politics, 28, 308-321. https://doi.org/10.2307/2127550

[34] Karenga, M. (1982) The Crisis of Black Middle Class Leadership: A Critical Analysis. The Black Scholar, 13, 16-32. https://doi.org/10.1080/00064246.1982.11414246

[35] Moore, D.S. (1999) The Crucible of Cultural Politics: Reworking “Development" in Zimbabwe's Eastern Highlands. American Ethnologist, 26, 654-689. https://doi.org/10.1525/ae.1999.26.3.654

[36] Baral, L.R. (1980) Nepal 1979: Political System in Crisis. Asian Survey, 20, 197-205. https://doi.org/10.2307/2644023

[37] Koirala, N. (1989) Nepal in 1989: A Very Difficult Year. Asian Survey, 30, 136-143. https://doi.org/10.2307/2644891 
[38] Hachhethu, K. (2007) Legitimacy crisis of Nepali Monarchy. Economic and Political Weekly, 42, 1828-1833. https://www.jstor.org/stable/4419602

[39] Crossette, B. (2005) Nepal: The Politics of Failure. World Policy Journal, 22, 69-76. https://doi.org/10.1215/07402775-2006-1010

[40] Wallace, P. (1969) India: The Leadership Crisis. Asian Survey, 9, 79-86. https://doi.org/10.2307/2642305

[41] Donald, L. (1970) Leadership in a Navajo Community. Anthropos, 65, 867-880.

[42] Hasan, M. (1998) Pathways of Political Leadership in South Asia: Limits and Possibilities. Economic and Political Weekly, 33, 585-588.

https://www.jstor.org/stable/4406522

[43] Hachhethu, K. (2007) Political Leadership in Nepal: Image, Environment and Composition. Contributions to Nepalese Studies, 34, 25-43. 